R. Increase in Candida krusei infection among patients with bone marrow transplantation and neutropenia treated prophylactically with fluconazole. $N$ Engl J Med 1991;325:1274-1277.

58. Antimicrobial prophylaxis in surgery. Med Lett Drugs Ther 1992;34:5-8. Medical Letter.

59. Hill RL, Duckworth GJ, Casewell MW. Elimination of nasal carriage of methicillin-resistant Staphylococcus aureus with mupirocin during a hospital outbreak. J Antimicrob Chemother 1988;22:377-384.

60. Wenzel RP, Nettleman MD, Jones RN, Pfaller MA. Methicillinresistant Staphylococcus aureus: implications for the 1990s and effective control measures. Am J Med 1991;91(suppl 3B):221S$227 \mathrm{~S}$.

61. Mulligan ME, Murray-Leisure KA, Ribner BS, et al. Methicillinresistant Staphylococcus aureus: a consensus review of the microbiology, pathogenesis, and epidemiology with implications for prevention and management. Am J Med 1993;94:313-328.

62. Boyce JM, Jackson MM, Pugliese G, et al. Methicillin-resistant Staphylococcus aureus (MRSA): a briefing for acute care hospitals and nursing facilities. Infect Control Hosp Epidemiol 1994:15:105-115.

63. Drutz DJ, vanWay MH, Schaffner W, Koenig MG. Bacterial interference in the therapy of recurrent staphylococcal infections. Multiple abscesses due to the implantation of the 502A strain of Staphylococcus. N Engl J Med 1966;275:1161-1165.

64. Light IJ, Walton RL, Sutherland JM, Shinefield HR, Brackvogel V. Use of bacterial interference to control a staphylococcal nursery outbreak. Am J Dis Child 1967;113:291-300.

65. Beck C, Necheles H. Beneficial effects of administration of Lactobacillus acidophilus in diarrheal and other intestinal disorders. Am J Gastroenterol 1961;35:522-530.

66. Surawicz CM, Elmer GW, Speelman P, McFarland LV, Chinn J, vanBelle G. Prevention of antibiotic-associated diarrhea by Saccharomyces boulardii: a prospective study. Gastroenterology 1989:96:981-988.

67. Tvede M, Rask-Madsen J. Bacteriotherapy for chronic relapsing Clostridium difficile diarrhoea in six patients. Lancet 1989;i:1156-1160.

68. Fekety R, Shah AB. Diagnosis and treatment of Clostridium difficile colitis. JAMA 1993;269:71-75.

69. Crocker IC, Liu WK, Byrne PO, Elliott TSJ. A novel electrical method for the prevention of microbial colonization of intravascular cannulae. J Hosp Infect 1992;22:7-17.

70. Segura M, Alia C, Valverde J, Franch G, Rodriguez JMT, SitgesSerra A. Assessment of a new hub design and the semiquantitative catheter culture method using an in vivo experimental model of catheter sepsis. J Clin Microbiol 1990;28:2551-2554.

71. Maki DG, Cobb L, Garman JK, Shapiro J, Ringer M. An attachable silver-impregnated cuff for prevention of infection with central venous catheter. Am J Med 1988;85:307-315.

72. Kamal GD, Pfaller MA, Rempe LE, Jebson PJR. Reduced intravascular catheter infection by antibiotic bonding. JAMA 1991;265:2364-2368

73. Kropec A, Huebner J, Frank U, Lemmen S, Hirt U, Daschner FD. In vitro activity of sodium bisulfite and heparin against staphylococci: new strategies in the treatment of catheter-related infection. J Infect Dis 1993;168:235-237.

74. Mermel LA, Stolz SM, Maki DG. Surface antimicrobial activity of heparin-bonded and antiseptic-impregnated vascular catheters. J Infect Dis 1993;167:920-924.

75. Bruderer U, Cryz SJ Jr, Schaad UB, Deusinger M, Que JU, Lang $\mathrm{AB}$. Affinity constants of naturally acquired and vaccineinduced anti-Pseudomonas aeruginosa antibodies in healthy adults and cystic fibrosis patients. J Infect Dis 1992;166:344-349.

76. Pennington JE. Impact of molecular biology on Pseudomonas aeruginosa immunization. J Hosp Infect 1988;11(suppl A):96-102.

77. Meyer KS, Urban C, Eagan JA, Berger BJ, Rahal JJ. Nosocomial outbreak of Klebsiella infection resistant to lategeneration cephalosporins. Ann Intern Med 1993;119:353-358.

78. Rice LB, Willey SH, Papanicolaou GA, et al. Outbreak of ceftazidime resistance caused by extended-spectrum beta-lactamases at a Massachusetts chronic-care facility. Antimicrob Agents Chemother 1990;34:2193-2199.

79. Naumovski L, Quinn JP, Miyashiro D, et al. Outbreak of ceftazidime resistance due to a novel extended-spectrum betalactamase in isolates from cancer patients. Antimicrob Agents Chemother 1992;36:1991-1996.

80. Brismar BO, Edlund C, Malmborg A-S, Nord CE. Ecological impact of antimicrobial prophylaxis on intestinal microflora in patients undergoing colorectal surgery. Scand J Infect Dis 1990;70:25-30.

\title{
TB Patients Feel Abandoned in Isolation
}

\section{by Gina Pugliese, RN, MS Medical News Editor}

A recent study published in the Journal of the Association of Nurses in AIDS Care reported the findings from interviews of $18 \mathrm{HIV}$-infected patients in respiratory isolation for TB in New York City. The survey revealed that the majority of patients often felt lone- ly and trapped and had disruption of sleeping and eating patterns. The patients also reported feeling stigmatized by the isolation and abandoned by the hospital staff. To improve isolation, the patients suggested increasing the amount of human contact and adding diversions.

The findings of this survey of isolation patients reminds us of the need to consider the patient's perspective in designing strategies to keep TB patients in their respiratory isolation rooms while they are infectious-a key infection control strategy.

FROM: Kelly-Rossini L, Perlman DC, Mason DJ. The experience of respiratory isolation from HIV-infected persons with tuberculosis. $J$ Assoc Nurses AIDS Care 1996;7(1):29-30. 